Archived version from NCDocks Institutional Repository http://libres.uncg.edu/ir/asu/

"The Strange Disappearance of State Investment in Human and Physical Capital in U.S. States," co-authored with Christopher Witko. I

Journal of Public Administration Research and Theory. /Forthcoming 2009. ISSN:

1053-1858

\title{
The Strange Disappearance of Investment in Human and Physical Capital in the United States
}

Christopher Witko, Adam J. Newmark

\begin{abstract}
Many scholars have argued that there are strong incentives for states to spend less money on redistributive or consumption programs, such as welfare, and more on developmental or investment programs, such as highways. Yet, over the last few decades, the proportion of state budgets allocated to expenditures intended to develop human and physical capital, specifically education and highways, has declined. In real terms, spending on virtually every government program has increased but expenditure increases to redistributive programs have been much greater than those to investment programs. Why this shift has happened despite theory predicting the contrary has not been adequately examined in a way that considers multiple developmental programs and multiple ways of conceptualizing spending over a substantial time period. We undertake this task in the following article using a large, cross-sectional time series data set of state budgeting toward K-12 education, higher education, and highways from 1965 to 2004 . We test competing theories of the determinants of state spending using these data and then discuss the factors that we believe have led to the relative deemphasis on developmental programs. We find that the most consistent predictors of state developmental spending patterns are federal grants, the state of the economy, and interstate and intrastate competition.

We are barraged daily with the consequences of America's apparent declining investment in its people and infrastructure. The deadly 2007 bridge collapse in Minnesota brought issues of highway maintenance and funding to the forefront (Saulny and Steinhauer 2007). The decline of the primary and secondary educational system
\end{abstract}


can be seen in comparison with other industrialized nations that produce a greater percentage of high school graduates and perform better on standardized tests (Basken 2006). Similarly, the US higher education system fails to provide enough educated and skilled professionals needed for the new information economy according to many experts. Even the state of California, long the leader in U.S. public higher education, is projected to see a deficit of needed college graduates within several years (Ferriss 2007). Though many people point to the federal government for solutions to these problems, these developmental programs have traditionally been largely funded and controlled by state governments.

Although spending on welfare programs has received a great deal of attention from political scientists, probably because of the controversial and therefore "political" nature of the issue area, a detailed understanding of why states spend money on developmental or investment programs is long overdue. Therefore, in the following article, we examine various theories of state budgetary decision making in order to understand why states allocate scarce resources to developmental or investment programs, which will ultimately shed light on why the relative allocations to these programs have been declining in recent years. We use the literature on state budgeting and studies of particular developmental programs to derive our theoretical expectations for changes in spending on K-12 education, higher education, and highways from 1965 to 2004. We consider demand for spending on particular programs, political factors such as partisanship and ideology, federal grants, interstate competition, intrastate budgetary tradeoffs, and economic context as possible determinants of state developmental spending decisions.

\section{Declining state investment?}

There is much discussion of America's declining investment in its people and infrastructure, and indeed, in recent decades, state support for education and highways, measured as a proportion of the average state budget, has declined substantially. According to Census Department data taken from the Annual Survey of State and Local Government Finances, in the late 1960s, the average state allocated approximately $59 \%$ of its own-source budget (i.e., excluding intergovernmental grants) to education (K12 and higher) and highways, but by 2004 , this average was approximately $42 \%$. There is variation to these patterns by expenditure program, however. Highways and higher education have steadily received a smaller percentage of the average state budget, whereas K-12 education's share of the average actually expanded slightly through the late 1990 s before contracting again in recent years. According to Census Department data, K-12 education's share increased from $21.5 \%$ to $23.9 \%$ of the average state ownsource budget between 1965 and 1999 and then declined to 19.98\% of the budget by 2004. This slight overall decrease in the proportion of state budgets allocated to $\mathrm{K}-12$ is significant considering that states now play a much larger role relative to local governments in the financing of public education in the states. According to Carey (2002), the percentage of funding for K-12 education coming from state governments has risen from 30\% to 49\% from 1940 to 1999. In other words, as the state government's role in K-12 education has expanded substantially, the proportion of state budgets devoted to K-12 had increased only slightly. In contrast to the overall increase 
for K-12 spending, during this same period, higher education's share of the average state budget decreased from $17.4 \%$ to $15.5 \%$ and highway spending decreased from $18.7 \%$ to $6.1 \%$ of the average state budget. Given that highway expenditures are often devoted to maintenance and upkeep, it is much easier to delay spending in this area (Garand and Hendrick 1991), and states have done this recently.

Viewing spending on these programs as a share of the budget partly distorts what has happened over the last several decades, however, since on a per capita basis, it has expanded. We note that even in the case of highways, which has seen the largest reduction of these programs in terms of budget share, per capita state own-source spending in inflation-adjusted dollars has actually risen from 1965 to 2004 by approximately $\$ 60$. Higher and K-12 educations have seen even larger per capita expenditure increases during the same time period ( $\$ 440$ and $\$ 590$, respectively). Spending on these programs as a proportion of the state's gross state product (GSP) or personal income has shown more variation but has increased substantially relative to the 1965 baseline though it is lower than during the peak years of the late 1960s. ${ }^{1}$ Measured as a percentage of personal income, spending on higher education and K-12 education has increased by about 50\% each between 1965 and 2004. Of course many would say that even the increases have not been enough given the even more rapidly increasing demands placed on the education system- more college attendees, more nonnative English speakers in many states, etc. In contrast, spending on highways measured as a percentage of personal income has actually declined by about $40 \%$ from 1965 to 2004.

Although absolute spending on developmental programs has actually increased over time, state government spending on other functions has obviously risen much more rapidly. For example, while spending on highways has increased by approximately $15 \%$, state own source spending on welfare has increased by approximately $360 \%$ between the 1960s and the 1990s. Additionally, spending on prisons, which constituted a very small portion of the typical state budget in the 1960 s, now consumes a fairly sizeable portion of the budget in some states. In a somewhat extreme example, projections indicate that in California spending on prisons will consume a larger portion of the budget than higher education by the year 2011 (Sterngold 2007). Thus, although spending on most government programs has increased in real terms, the relative increase on highways and higher education has been substantially lower than other government programs, resulting in these programs receiving a smaller proportion of state budgets.

Jones (1990) calls expenditures on these education and transportation programs "investment spending" because they replenish the tax base by expanding subsequent economic growth, whereas other scholars call them developmental spending (Peterson 1995). We use the terms interchangeably throughout this article. While Jones (1990) notes that all spending has multiple purposes and consequences, welfare and health care, which are among the largest categories of state spending, are generally

\footnotetext{
${ }^{1}$ GSP data are not available for all states prior to the 1980 s, so we use spending as a percentage of personal income throughout this article.
} 
considered consumption or redistributive spending; transportation (traditionally highways) and increasingly education are considered investment or developmental spending (Brace 1993; Hwang and Gray 1991; Jones 1990; Peterson 1995; Smith and Rademacker 1999$)^{2}$ because they are alleged to increase business investment and increase economic growth and development. For example, spending on highways may attract businesses that can use this system to distribute their products. Similarly, education spending may increase productivity by producing higher skilled employees, and businesses may wish to expand, invest, or locate in an area with better schools that are given more resources by the government. This does not mean that all state policy makers view these programs in such black or white terms. For example, Bailey, Rom, and Taylor (2004) find that states appear to view higher education as consumption or redistributive rather than developmental spending. Nonetheless, it is intuitive that over the long run, a failure to invest in these developmental programs will lead to lower rates of economic growth in the future. Jones (1990) finds that state education and highway spending appear to positively influence economic growth in some time periods, but statistical studies have not been able to examine the long-term influence of these expenditures because we lack systematic, state-level data prior to the 1950 s.

Why state governments have reduced the proportion of government spending on these investment programs is puzzling in light of the existence of theories that claim that states should compete to have economies most attractive to business investment. According to Peterson (1995), subnational governments should therefore feel pressure to reduce expenditures on redistributive programs and increase expenditures on developmental programs. This has not happened, but there remain pressures on state policy makers to respond to mandates of the federal government or state or federal courts.

We do not know for certain why states have made these decisions. Compared to expenditures on welfare programs, developmental programs have been studied less often, presumably, because of their more consensual nature which makes them less interesting to scholars. Yet developmental programs are clearly very important and still constitute a large portion of the typical state budget, and therefore, understanding why states spend what they do on these programs is critically important. Although state budget allocations to these programs have generally been similar, there is still substantial variation across the states. We therefore seek to better understand the factors that influence state expenditures on developmental programs.

\section{Explaining State Allocations To Developmental Programs}

There are several factors that research on state budgets indicates should influence spending on developmental programs. In the following section, we discuss the most important of these factors-federal policies, economic cycles, competition (from other states and for programs within states), and state politics. We then test the influence of

\footnotetext{
${ }^{2}$ In his earlier work, Peterson (1981) views education spending as allocational rather than developmental, but more recent work generally considers education spending to be developmental (Hwang and Gray 1991; Smith and Rademacker 1999).
} 
these factors using a substantial data set on state budgets from 1965 to 2004 .

\section{Fiscal Federalism}

Many scholars have noted that federal policies influence state spending decisions through federal mandates and the grant-making process (Nice 1987). Different grants are designed to achieve different ends, but in general, scholars have found that $\$ 1$ in grant money leads to a greater spending increase than a dollar in tax revenue would, which has been called the "flypaper effect" (Hines and Thaler 1995). For example, Kane, Orszag, and Gunter (2002) argue that changes in the federal Medicaid program appear to have resulted in an increase in state spending on this program and a reduction in higher education spending. Nicholson- Crotty, Theobald, and Dan Wood (2006) show that the pattern of federal grants to the states creates incentives for states to spend on certain programs and not on others.

]

Programs that require matching expenditures should most likely stimulate greater state spending, though scholars have observed the flypaper effect even with grant programs that do not require matching (Chubb 1985; Dye 1988). There is by no means universal agreement on the effect that federal grants have on spending, however. For example, Bailey and Rom (2004) fail to observe any relationship between federal grants and state own-source spending on welfare, and Knight (2002) argues that empirical support for the flypaper effect results from model misspecification. Despite the disagreement, it is clearly necessary to account for the possible effect of federal grants on state spending. We expect that greater emphasis in federal grant making on developmental programs will result in greater state spending on these programs.

\section{Economic Cycles}

Additionally, state governments tax and spend in the context of economic cycles of rising and falling growth. When income and economic growth increase, states collect more tax revenue enabling more developmental spending since these investments in human and physical capital often require large expenditures without any immediate benefit in terms of economic growth. Kane, Orszag, and Gunter (2002) point out that investment in higher education is highly cyclical with increases during good economic times. It is no coincidence that such examples of state investment as the system of colleges and universities in California were financed during the long postwar economic boom of the 1950s and 1960s. Conversely, during economic downturns, investment spending is often reduced. This is especially likely to be the case with transportation and spending on higher education. For higher education programs, spending reductions are often offset with tuition or fee increases on students or salary or hiring freezes. Similarly, transportation projects are often delayed until the budget outlook improves (Garand and Hendrick 1991), and thus, states should allocate relatively more money to education and highway programs during economic expansions and less during recessions.

\section{Intrastate Competition, Interstate Competition, and Demand}


We consider both interstate and intrastate competition as factors that may influence state spending on developmental programs. The intrastate competition surrounding the budget process is characterized by the unlimited wants of different constituencies and the finite resources that government has to provide for these needs in a given fiscal year.

The policy determinants literature has observed a strong relationship between demographics and state spending (Dye 1966, 1979).Onereason for this is that demographics reflect varying levels of demand for public services, and the composition of state budgets partly reflects these competing demands for government services. Any analysis of state expenditures must account for this demand function. For example, a state with many children will have a greater demandfor education compared to a state with few children, and this should increase education spending (Dye 1988). Similarly, a state with many automobile users may also have greater demand for spending on highways than a state with fewer automobiles.

There are also constituencies that demand nondevelopmental or consumption spending programs like health care and welfare. The demand for this type of government spending is likely to be greatest in states with larger numbers of poor people or those who can most afford it. To the extent that the demands for more consumption spending are met, this should influence reductions in allocations to developmental programs due to the existence of budgetary trade-offs (Berry and Lowery 1990; Nicholson-Crotty, Theobald, and Dan Wood 2006; Garand and Hendrick 1991; Hendrick and Garand 1991). As noted above, Kane, Orszag, and Gunter (2002) argued that the expansion of the federal Medicaid program in the 1990s resulted in states spending more on this health care program and less on higher education.

However, spending in various budgetary categories may be independent of each other (Gray 1974), or spending in multiple categories may ebb and flow together. Wildavsky (1964) described this in terms of obtaining a "fair share" of the budget, whereas Hendrick and Garand (1991) noted the "mutual change" in different policy areas.

We also consider interstate competition as a possible influence on state developmental spending decisions. Since subnational politicians in the United States are mostly reliant on the investment decisions of the private sector to create economic growth in their region, they will often feel pressure to enact policies that create what Lindblom (1977) called "a positive business investment climate." Consequently, scholars have considered how economic competition may influence fiscal policy. Since the attractiveness of the investment climate is relative, we expect that as competitor states enact fiscal policies favored by private sector investors, states will feel pressure to do so as well. For example, Phillips (2004) finds that states altered their tax policies in response to changes in their economic and regional competitors' policies. On the spending side of fiscal policy, Peterson $(1981,1995)$ argues that economic competition leads to the underprovision of redistributive or consumption programs (e.g., welfare) at the state and local level because these programs increase taxes but do not increase productivity and therefore are repellent to private investors. This argument has received 
a great deal of scholarly attention in the "race to the bottom" debate examining welfare expenditures (Bailey and Rom 2004; Lurie 1998; Schram 1998) and higher education (Bailey, Rom, and Taylor 2004).

The flip side of tax competition and a race to the bottom in welfare spending may be that states compete in something like a "race to the top" to have public services that are attractive to business investors. Although the redistributive aspect of Peterson's (1981, 1995) argument has received more attention from political scientists, he also argues that state and local governments are pressured to increase developmental expenditures. In discussing why states may even occasionally choose to raise taxes to promote economic growth, Phillips $(2004,17)$ notes that "the market model posits that mobile actors are as concerned about the level and types of public goods that are provided by the states as they are with their annual tax bill." Or, as Saiz $(2001,205)$ explains, businesses "shop" for the mix of public goods that they prefer. Keen and Marchand $(1997,49)$ demonstrate that interjurisdictional economic competition can lead to the "under provision of items that confer direct consumption benefits" and the "over provision of public inputs," such as infrastructure investments.

Bailey, Rom, and Taylor (2004) are agnostic about whether spending on higher education is developmental or redistributive and take an empirical approach to answering this question. They reason that if states view spending on higher education as redistributive, there will be a race to the bottom with states that spend more reducing spending more rapidly than states that spend less, and if states view spending on higher education as an investment, there will be a race to the top with states spending less increasing their expenditures more, ceteris paribus. They test these possibilities with two variables that allow for an examination of whether states that spend more on higher education than their neighbors reduce expenditures more rapidly than states that spend less than their neighbors on higher education. If anything, they find a race to the bottom for higher education, though this is not consistent across all models.

\section{Partisanship and Ideology}

Phillips (2004) finds that both economic competition and state politics influence state tax policy, and this might very well be the case here as well. Although early scholarship demonstrated that state politics had little influence on state budgets (Dye 1966), more recent work generally confirms an important if subtle role for state politics in determining the size (Alt and Lowery 2000) and composition of state budgets (Garand 1985; Hwang and Gray 1991; Jacoby and Schneider 2001). On balance, the strongest relationship between politics and spending is evident on welfare programs, whereas spending on education and highways appears relatively less dependent on political factors, perhaps, due to the more consensual and less ideological nature of these programs (Hwang and Gray 1991). Nonetheless, we believe it is wise to consider the relationship between politics and investment spending for the reasons stated below.

Ideology and partisanship may have separate effects on spending, however. In general, although conservatives have traditionally been opposed to large budgets, they have been more favorably disposed toward spending on infrastructure that is thought to 
promote economic growth and development. In addition, the Democratic Party has been more clearly affiliated with the poor and working class, whereas Republicans have been more closely aligned with business. Therefore, taking spending levels as a given, we expect to see conservative and Republican states more likely to increase spending on developmental programs like education and highways (Nicholson-Crotty, Theobald, and Dan Wood 2006). Alt and Lowery (2000) find that changes in partisan control of government lead to changes in the size of the budget, and we also expect the greatest changes in the composition of spending following a change in party control.

\section{Data and Methods}

To examine the relationships discussed above, we examine data covering 49 states (excluding Nebraska because it has a nonpartisan legislature) for the time period of 1965-2004. The number of cases varies depending on missing data and the lags used for the independent variables, but for each of our models, we have at least 1692 observations.

\section{Dependent Variables}

We examine state own-source expenditures from 1965 to 2004 devoted to (a) highways, (b) higher education, and (c) K-12; since these are by far the largest expenditures that constitute investments in physical and human capital, all states support such programs and they have been in existence for the entire time period under review. Scholars typically measure state fiscal effort in one of three ways: by examining budget shares, by examining dollars spent (aggregate or per capita), or by examining spending as a share of the total potential resources that could be devoted to governments, such as GSP or state personal income. Depending on the measure of spending we choose, we could observe very different patterns in the data. As we noted above, while developmental spending has decreased as a percentage of the budget, in real terms, spending on developmental programs has increased.

There are arguments in favor of each of these types of dependent variables. Regarding budget shares, scholars have convincingly argued that budget allocations to various programs are what Berry and Lowery (1990) call "Fixed Pool Simultaneous," meaning that the size of the budget is determined prior to the allocations to particular categories (see also Nicholson-Crotty, Theobald, and Dan Wood 2006). If this is correct, then the appropriate question is, given a particular level of spending, how much is allocated to developmental programs? Using budget shares to programs that comprise the entire state budget would introduce problems associated with the analysis of compositional data and makes ordinary least squares (OLS) estimation procedures suspect (Katz and King 1999). Yet in this instance, we use changes to budget allocations to programs that comprise only about half of the typical state budget, meaning that strictly speaking, our budget data are not compositional, and if other assumptions hold, OLS is the correct estimation procedure. ${ }^{3}$

\footnotetext{
${ }^{3}$ If we were examining all budget categories in this analysis, our data would be compositional since changes in, say, eight of nine categories would perfectly predict change in the ninth category. Here, however, all programs could increase or decrease independently of one another (cf., Gray 1974) meaning that errors are not inherently correlated across equations and separate OLS regressions are appropriate. We can easily transform our data into compositional data by creating an "other" category and using appropriate compositional methods, but this is not necessary and OLS is much simpler to estimate and interpret.
} 
Although it seems that budget makers start with general spending levels and then make allocation decisions, there are obviously other possibilities and using budget shares can also obscure some of the dynamics of state spending. For example, K-12 education spending has increased quite a bit since the 1960s, but looking only at budget shares, one does not get this impression. Rather than limiting themselves to a fixed amount, budgeters may decide to increase spending on developmental programs but increase spending more on other programs and proceed to do this by expanding the entire size of government. This suggests using either some dollar measure of spending or examining spending as a percentage of the economy. Each of these alternative measures to budget shares also has drawbacks. For example, the measure of spending as a percentage of personal income can change even without any changes in spending because of annual fluctuations in the amount of personal income. Similarly, measuring spending on a per capita basis will also be partly influenced by population changes rather than changes in fiscal policy; however, with the exception of rapidly growing or shrinking population states, these effects will be modest. Since each measure only paints part of the picture, we analyze all three types of dependent variables and present and discuss the influences on them. Specifically, our dependent variables are the change in budget shares devoted to these programs, changes in per capita expenditures on these programs, and changes in expenditures as a percentage of total state personal income, a measure of the total size of the state's resources that could be potentially used for government. ${ }^{4}$ Thus, we present nine models below. ${ }^{5}$ The data come from the Census Bureau's Annual Survey of State and Local Government Finances for each year from 1965 to 2004. Given the differences in what these dependent variables measure, we do not expect the models to produce identical results and making firm conclusions will be somewhat difficult, yet this analysis will produce a more complete picture of the ways that the factors discussed above shape state spending on developmental programs.

\section{Independent Variables}

In each part of the analyses, we consider federal grants, economic growth cycles, intrastate competition in terms of demand for various programs, interstate economic competition, and the partisanship and ideology of state government. Federal grant data were also obtained from the Census Bureau Data Set. When considering budget shares and share of personal income, the Federal grants variable included in each equation is the percentage of total federal grants to the state comprised of the spending category of interest. For example, in the analysis examining highway spending, it is the percentage of total federal grants to the state intended for the highway program. We construct a

\footnotetext{
${ }^{4}$ We did consider examining this as a percentage of GSP; at any rate, the two variables are highly correlated.

${ }^{5}$ The summary statistics for variables for proportion of the budget are as follows with differenced values in parentheses: highway spending, 0.01 (20.11) to 0.29 (0.11) with mean of 0.11 (20.003) and standard deviation of 0.05 (0.017); higher education spending, 0.05 (20.07) to 0.41 (0.06) with a mean of 0.18 (20.0005) and standard deviation of 0.06 (0.014); K-12 spending, 0.01 (20.20) to 0.58 (0.22) with a mean of 0.23 (20.0004) and standard deviation of 0.08 (0.027). In per capita dollars: highways, 22.53 (20.491.09) to 1448.09 (706.34) with a mean of 203.94 (1.48) and standard deviation of 98.65 (43.20); higher education, 71.37 (20.207.08) to1013.50 (274.99) with a mean of 363.88 (11.30) and standard deviation of 143.87 (31.25); K-12 education, 7.54 (2.690.84) to 2354.34 (640.98) with a mean of 487.53 (15.10) and standard deviation of 249.98 (58.37). As a percentage of personal income: highways, 0.001 (20.01) to 0.045 (0.02) with a mean of 0.01 (20.0002) and standard deviation of 0.005 (0.002); higher education, 0.004 (20.009) to 0.037 (0.009) with a mean of 0.016 (0.0001) and standard deviation of $0.006(0.001)$; K-12 education, 0.001 (20.02) to $0.073(0.03)$ with a mean of 0.021 (0.0002) and standard deviation of 0.008 (0.003).
} 
similar measure for each of the other spending areas. In the per capita expenditure models, the relevant variable is per capita federal grants, and in the share of personal income model, it is grants as a share of personal income.

To account for the cyclical nature of investment spending, we include a measure of the state's personal income growth rate in the budget share model. This variable is the percentage growth rate and ranges from positive values during periods of economic expansion to negative values during recessions. We expect that during periods of economic expansion, we should see increases in expenditures in each of our spending areas. Since personal income growth is already included in the dependent variable for the personal income share models, we do not include this variable in those models. For the per capita spending models, we include a measure of the change in per capita personal income.

It is also necessary to consider the competing demand for various forms of spending which may positively or negatively shape state investment spending depending on the levels of demand (Nicholson-Crotty, Theobald, and Dan 2006; Dye 1988). The variables that we use in the analyses below are K-12 enrollment (for education), the number of Registered vehicles in each state (for highways), and the number of Aid to Families with Dependent Children/Temporary Assistance for Needy Families (AFDC/TANF) recipients to control for the counterdemand for welfare and health care spending (for both education and highways). ${ }^{6}$ To test for the possibility of trade-offs, we include the demand variable associated with alternative programs since including the actual spending for alternative programs in the equations can produce biased estimates (Berry and Lowery 1990; Nicholson-Crotty, Theobald, and Dan Wood 2006). The demographic data were collected from the Statistical Abstract of the United States, which are now available on the US Census Bureau Web Site. We use the number of individuals per thousand population in the budget share and personal income share models. In the per capita spending models, we use the change in the raw number.

We consider both partisan control and ideology as political determinants of spending. The updated data set of Fording and Berry is used for the Government ideology variable (cf. Berry, Ringquist, Fording, and Hanson 1998). This variable should have a negative influence on the budget share models since liberal governments will spend relatively less on developmental spending but should have a positive coefficient in the equation with the other two dependent variables because liberal governments will likely spend more money overall on all government functions. The data for the partisan control of government were collected from The Book of the States (Council of State Governments 1964-2004). We created three partisan control variables: one representing Unified Republican control of the legislature, one representing Unified Democratic control, and one denoting a Republican Governor. Because it has a unicameral nonpartisan legislature, Nebraska was excluded from the analysis. Since budgets should be most likely to change with a shift in partisan control (Alt and Lowery 2000), we use the

\footnotetext{
${ }^{6}$ Federal welfare reform legislation led to important changes in eligibility for welfare programs which may threaten the validity of combining AFDC/TANF recipients in one variable. However, the reduction in AFDC recipients in the year prior to the passage of welfare reform (1995-96) was nearly equal to the reduction in 1996-97 indicating that welfare reform probably does not threaten the validity of this measure.
} 
change in partisan control. For example, if the legislature came under unified control of the Republican Party, the variable Unified Republican would take on the value of 1 , and if it switched from Unified Republican to some other partisan arrangement, this variable would take on the value of 21; if the Republicans maintained their status, it would be coded as 0 . The other party control variables are coded similarly. Since we examine changes in, rather than party control itself, the fact that Democratic states in the South were also conservative does not confound the effects of party and ideology in that region.

To examine the effects of regional economic competition, we need to examine how states respond to changes in their competitors' developmental spending. To do this, we follow the procedure used by Bailey, Rom, and Taylor (2004) to examine the influence of competition on state spending on higher education. Specifically, we created two variables that examine how states respond to changes in spending by neighboring states, which are the states most likely to compete with one another (Bailey, Rom, and Taylor 2004). The first variable is called convergence, which is the difference between the average percentage of the budget allocated to a given budget program in neighboring states and the state's own percentage allocated to the program. The second variable is called competition and is simply the value of the convergence variable where it is greater than 0 . These two variables together allow us to examine whether states with a relatively higher proportion of their budget devoted to developmental programs reduce allocations more or less rapidly than states that spend less than their neighbors on developmental programs. In the absence of interstate competition, neighboring states may still have similar spending patterns for any number of reasons implying that states with relatively higher spending than their neighbors would spend less in the future; the convergence variable coefficient would thus be negative and significant, whereas the competition variable coefficient would not be significant. In a race to the bottom, coefficients for both variables would be negative and significant, indicating that states with greater allocations to developmental programs than their neighbors reduce allocations and that they reduce them more rapidly than states with lower allocations to these programs. In a race to the top, the convergence variable coefficient should not be significant since all states will be increasing expenditures, whereas the competition variable coefficient would be negative and significant, indicating that high spending states increase expenditures less rapidly.

\section{Model Specification}

Our data are time series cross-sectional which can present several potential estimation problems that have been discussed at length, most notably by Beck (2001) and Beck and Katz (1995). First, unobserved variables are likely to have unit-specific or timespecific effects that are not captured in the measured independent variables. For example, states have various $\mathrm{K}-12$ funding mechanisms which cause wide discrepancies in the dependent variable absent the influence of any of the theoretically interesting causal factors that we wish to investigate. These differences, if uncontrolled, can cause heteroskedasticity since our statistical model will better explain the variation in some units than others. To control for these unit-specific and time-specific effects, we estimate two-way fixed-effects models. 
Two additional problems that are common with time series data are autocorrelation of residuals and the presence of a unit root (i.e., integration). Each problem is present to a degree in the various models presented below. The raw dependent variables are not integrated but are, perhaps, most accurately described as near integrated. ${ }^{7}$ Some of the models using these data also demonstrate positive autocorrelation in the residuals. A common approach when data are integrated is differencing, which does eliminate such problems in this case. Unfortunately, this procedure exacerbates problems of autocorrelation by creating residuals that are negatively autocorrelated for one or two periods depending on which spending variable is used. ${ }^{8}$ Integration and autocorrelation can both produce estimation problems, but the autocorrelation problems can be addressed rather easily by including lags of the dependent variable on the right-hand side of the model. Therefore, we differenced the dependent variables and include the appropriate number of lags of the dependent variable to eliminate autocorrelation in the residuals for each of the models. We also tested for more complicated dynamics than one period lags, but these models did not fit the data well. ${ }^{9}$ Given the dependent variables, we also differenced the independent variables, except in the cases of the state ideology variable which changes very little within states in a given year and the competition and convergence variables since we think that given the dynamics of competition, states will react to their neighbor's level of spending in the last budget cycle rather than the recent changes in their expenditure patterns.

Choosing the proper lag length between the independent and dependent variables is not entirely straightforward since some states have annual budget cycles, whereas other states use a biennial process. Even in states that use a biennial process, however, mid-cycle adjustments are possible, and therefore, we use one period lags in the models presented below. Our choice of lagging the competition variable allows for the use of relatively simpler estimation procedures (Bailey, Rom, and Taylor 2004) than if we chose to model contemporaneous changes which would require the use of simultaneous or two-stage equations (see Phillips 2004). This choice of using a one period lag is more than a statistical convenience as it reflects a statement about the causal process by which states respond to their competitors. Essentially, our model assumes that states do not respond immediately to changes in the expenditure patterns of their competitors but do respond rather quickly (in the next period). We find this to be the best approximation of reality, especially, since many states have biennial budgeting. We did examine various lag lengths, for each model, and use a second lag in the higher education models.

\section{Influences On State Developmental Spending}

Tables 1, 2, and 3 show models of our spending variables for highways, higher education, and K-12 education, respectively, regressed on the independent variables

\footnotetext{
${ }^{7}$ A simple autoregression equation indicates coefficients ranging from 0.91 to 0.96 for the nine dependent variables.

${ }^{8}$ We tested for autocorrelation using Lagrange Multiplier tests.

${ }^{9}$ Specifically, we considered the possibility of error-correcting relationships between the dependent variables and some of the independent variables and also the possibility of the presence of a linear trend, which seemed particularly likely in the case of highway spending which has declined steadily over the last few decades. Neither of these processes fit the data well judging by the persistence of autocorrelation.
} 
discussed above. In each table, the first column presents the analysis examining spending as a share of the budget, with the per capita models in the middle, and the personal income share models on the right. We include fixed effects for both states and years but do not present the results because they are of little substantive interest.

Beginning with the highway spending model, we can see with the negative and significant coefficient on the lagged dependent variable that regardless of the dependent variable, a large increase in spending is unlikely to be followed by an additional large increase in spending (see table 1). As expected, the convergence variable is negative and significant across all models demonstrating that states spending a relatively high amount compared to their neighbors will spend less in the next period and vice versa. In the per capita expenditure models, the coefficient for the demand variable, registered vehicles, is positive and significant, but whereas positive, it is not significant in the other models. The federal highway grant variable is significant in the budget share model and is positive but insignificant in the remaining models (though nearly significant in the personal income share model). The ideology variable is negatively signed and significant in all models, indicating that liberal governments will allocate less money as a proportion of total spending to highways, as expected, but will also allocate fewer resources overall than less liberal states controlling for other factors. The personal income variable demonstrates that increases in economic growth will be followed by a greater proportion of the budget allocated to highway spending, perhaps, because the greater growth alleviates some of the pressure to increase-

Table 1

Determinants of the Changes in State Spending on Highways, 1965-2004

\begin{tabular}{|c|c|c|c|}
\hline Variable & $\begin{array}{l}\text { As Proportion } \\
\text { of Budget }\end{array}$ & $\begin{array}{l}\text { Per Capita } \\
\text { Dollars } \\
\end{array}$ & $\begin{array}{l}\text { As Proportion of } \\
\text { Personal Income }\end{array}$ \\
\hline Past spending ${ }_{t-1}$ & $-0.138 * *(0.038)$ & $-0.226^{* *}(0.080)$ & $-0.161 * *(0.059)$ \\
\hline Federal grants $_{t-1}$ & $0.035^{* *}(0.013)$ & $0.048(0.085)$ & $0.079(0.060)$ \\
\hline $\mathrm{K}-12$ enrollment $_{t-1}$ & $-0.067(0.048)$ & $-0.006(0.009)$ & $-0.000(0.005)$ \\
\hline Registered vehicles $_{t-1}$ & $0.005(0.010)$ & $0.006^{*}(0.003)$ & $0.001(0.001)$ \\
\hline AFDC/TANF recipients ${ }_{t-1}$ & $-0.131(0.129)$ & $0.006(0.026)$ & $-0.001(0.016)$ \\
\hline Government ideology $_{t-1}$ & $-0.00004 *(0.00002)$ & $-0.104 *(0.054)$ & $-0.00005 *(0.00000)$ \\
\hline Republican Governor $_{t-1}$ & $0.000(0.001)$ & $-3.046(4.214)$ & $-0.000(0.000)$ \\
\hline Unified Republican legislature $_{t-1}$ & $-0.000(0.002)$ & $-3.045(4.902)$ & $-0.000(0.000)$ \\
\hline Unified Democratic legislature $_{t-1}$ & $0.001(0.001)$ & $0.268(3.914)$ & $0.000(0.000)$ \\
\hline Compete $_{t-1}$ & $0.017(0.046)$ & $-0.056(0.955)$ & $-0.010(0.075)$ \\
\hline Converge $_{t-1}$ & $-0.282 * * *(0.034)$ & $-0.149 * *(0.040)$ & $-0.207 * *(0.037)$ \\
\hline Personal income ${ }_{t-1}$ & $0.023 *(0.012)$ & $0.001(0.004)$ & - \\
\hline$\Delta$ Expenditure & - & - & $0.085^{* *}(0.018)$ \\
\hline Constant & $0.012 * *(0.004)$ & $51.822 *(23.442)$ & $0.000(0.000)$ \\
\hline$N$ & 1790 & 1839 & 1692 \\
\hline$R^{2}$ & .280 & .223 & .309 \\
\hline
\end{tabular}


Table 2

Determinants of the Changes in State Spending on Higher Education, 1965-2004

\begin{tabular}{|c|c|c|c|}
\hline Variable & $\begin{array}{c}\text { As Proportion } \\
\text { of Budget }\end{array}$ & $\begin{array}{c}\text { Per Capita } \\
\text { Dollars } \\
\end{array}$ & $\begin{array}{l}\text { As Proportion of } \\
\text { Personal Income }\end{array}$ \\
\hline Past spending $t-1$ & $-0.159^{* *}(0.041)$ & $-0.169 * *(0.052)$ & $-0.165 * *(0.489)$ \\
\hline Past spending ${ }_{t-2}$ & $-0.096 *(0.039)$ & $-0.085^{*}(0.051)$ & $-0.112 *(0.047)$ \\
\hline Federal grants gr-1 $_{t}$ & $0.044 * *(0.013)$ & $0.197 * *(0.062)$ & $0.169^{* *}(0.052)$ \\
\hline $\mathrm{K}-12$ enrollment $_{t-1}$ & $0.057(0.040)$ & $0.000(0.008)$ & $0.005(0.004)$ \\
\hline Registered vehicles $_{t-1}$ & $0.006(0.009)$ & $0.002(0.002)$ & $0.001(0.001)$ \\
\hline AFDC/TANF recipients ${ }_{t-1}$ & $-0.271 * *(0.097)$ & $-0.006(0.019)$ & $0.003(0.001)$ \\
\hline Government ideology $_{t-1}$ & $-0.000(0.000)$ & $0.006(0.045)$ & $-0.000(0.000)$ \\
\hline Republican Governor $_{t-1}$ & $-0.001(0.001)$ & $-4.425(2.854)$ & $-0.000(0.000)$ \\
\hline Unified Republican legislature $t_{t-1}$ & $-0.001(0.001)$ & $-1.029(3.035)$ & $-0.000(0.000)$ \\
\hline Unified Democratic legislature $_{t-1}$ & $-0.002(0.001)$ & $-3.887(2.772)$ & $-0.000(0.000)$ \\
\hline Compete $_{t-1}$ & $-0.007(0.033)$ & $-0.051(0.042)$ & $-0.016(0.046)$ \\
\hline Converge $_{t-1}$ & $-0.134 * *(0.025)$ & $-0.068 * *(0.026)$ & $-0.120 * *(0.029)$ \\
\hline Personal income ${ }_{t-1}$ & $0.002 *(0.010)$ & $0.002(0.002)$ & - \\
\hline$\Delta$ Expenditures & - & - & $0.088 * *(0.010)$ \\
\hline Constant & $-0.010 * *(0.002)$ & $31.072 * *(7.593)$ & $-0.001 * *(0.000)$ \\
\hline$N$ & 1793 & 1793 & 1646 \\
\hline$R^{2}$ & .233 & .297 & .371 \\
\hline
\end{tabular}

alternative types of social spending. Highway spending responds most consistently to past spending changes, government ideology, and the spending patterns of other states, with other variables attaining statistical significance depending on the model.

Table 2 presents the results of the three models for higher education spending. Like highway spending, the lagged dependent variable coefficient is negative and significant in each model. To correct for autocorrelation, we include two lags of the dependent variable, and both are negative and significant, indicating that a large increase in allocations to higher education will limit additional allocations for 2 years. In addition, the federal grant variable is positive and significant across all three dependent variables, indicating that regardless of how we measure state higher education effort, federal education grants are an important determinant of state spending on higher education. ${ }^{10}$ In the budget share model, the personal income variables and the AFDC/TANF variable are also significant in the expected direction, but they are not in the other models. The significant finding for the AFDC variable in the first higher education model is consistent with Kane, Orszag, and Gunter's (2002) study finding that expansions in eligibility for the Medicaid program (which is jointly funded by the federal government and states) have led to a reduction in state spending on higher education. However, we find that

\footnotetext{
${ }^{10}$ Due to data limitations, we were not able to separate higher education and K-12 education aid, but education aid has a statistically significant, positive coefficient, suggesting that this aid is also estimated to increase higher education spending.
} 
increasing numbers of AFDC/TANF recipients leads only to a relative and not absolute reduction in higher education expenditures.

Table 3

Determinants of the Changes in State Spending on K-12 Education, 1965-2004

\begin{tabular}{|c|c|c|c|}
\hline Variable & $\begin{array}{l}\text { As Proportion of } \\
\text { Budget }\end{array}$ & $\begin{array}{l}\text { Per Capita } \\
\text { Dollars } \\
\end{array}$ & $\begin{array}{l}\text { As Proportion of Personal } \\
\text { Income }\end{array}$ \\
\hline Past spending $t-1$ & $-0.126^{* *}(0.042)$ & $-0.060(0.056)$ & $-0.068(0.052)$ \\
\hline Federal grants sel $_{t-1}$ & $0.076^{* *}(0.027)$ & $-0.072(0.166)$ & $0.086(0.114)$ \\
\hline $\mathrm{K} 12$ enrollment $_{t-1}$ & $0.131(0.127)$ & $0.037 *(0.017)$ & $0.008(0.008)$ \\
\hline Registered vehicles $_{t-1}$ & $0.008(0.019)$ & $0.002(0.005)$ & $0.002(0.002)$ \\
\hline AFDC/TANF recipients ${ }_{t-1}$ & $-0.593 * *(0.201)$ & $-0.090 *(0.041)$ & $-0.035^{*}(0.021)$ \\
\hline Government ideology $y_{t-1}$ & $0.001(0.000)$ & $0.168 *(0.074)$ & $0.000006 *(0.000003)$ \\
\hline Republican Governor $_{t-1}$ & $0.001(0.002)$ & $-5.210(6.014)$ & $0.000(0.000)$ \\
\hline Unified Republican legislature $_{t-1}$ & $0.001(0.003)$ & $2.585(6.336)$ & $0.000(0.000)$ \\
\hline Unified Democratic legislature $_{t-1}$ & $-0.002(0.003)$ & $-7.078(5.593)$ & $-0.000(0.000)$ \\
\hline Compete $_{t-1}$ & $-0.080 *(0.036)$ & $-0.021(0.053)$ & $-0.042(0.050)$ \\
\hline Converge $_{t-1}$ & $-0.082 *(0.022)$ & $-0.088 * *(0.026)$ & $-0.110 * *(0.025)$ \\
\hline Personal income ${ }_{t-1}$ & $0.047 *(0.021)$ & $0.011 * *(0.005)$ & - \\
\hline$\Delta$ Expenditures & - & - & $0.086^{* *}(0.021)$ \\
\hline Constant & $-0.001(0.005)$ & $42.494 *(21.388)$ & $0.001(0.001)$ \\
\hline$N$ & 1793 & 1842 & 1695 \\
\hline$R^{2}$ & .199 & .119 & .180 \\
\hline
\end{tabular}

As with highway spending, the convergence variables are negative and significant in all three models, indicating that states spending more than their neighbors will increase spending to a lesser extent than their neighbors who spend less. Surprisingly, none of the political variables are significant predictors of spending on higher education.

Turning to the K-12 spending models (table 3), we again see that the coefficient on the lagged dependent variable is negative in all three models but is significant in only the budget share model in column 1 . This indicates that states that spend a large proportion of their budget on $\mathrm{K}-12$ increase that proportion less substantially, but this relationship does not hold for the other models. Federal grants are also positive and significant in the budget proportion model but not in the models analyzing the other dependent variables. The lack of significance for the coefficients of these variables is surprising. The coefficient for the personal income variable is significant and positive in both models in which it is included, indicating that when there is positive economic growth, states will invest more in $\mathrm{K}-12$ education. We again see a negative relationship between the number of AFDC/TANF recipients and education spending, but for this spending area, the relationship is negative and significant across all three dependent variables. This indicates that there is a consistent relationship between increased demand for social service spending and a relative reduction in K-12 spending. In all three models, 
the coefficient for K-12 enrollment is positive, but only in the per capita spending model, does it achieve statistical significance. Unlike higher education spending, government ideology is a positive and significant predictor of state K-12 spending on a per capita basis and as a share of the state's total personal income. It is not estimated to influence the proportion of the budget, however.

As with the other two types of spending, the convergence variable is negative and significant across all three models. In the budget share model, the competition variable is also negative and significant indicating that states with higher spending as a proportion of their budget reduce relative expenditures on K-12 education to a greater extent than other states, evidence of a race to the bottom. This competition variable is negatively signed but not significant in the other models, which indicates that only budget shares (and not actual dollars or the percentage of spending on K-12 education as a percentage of personal income) demonstrate this dynamic. Thus, we can conclude that states with a higher share of their budgets devoted to $\mathrm{K}-12$ have reduced this percentage to a greater extent, but this has not translated into fewer resources overall devoted to K-12 education.

Though there are commonalities across our models, we do note a number of differences in each spending area and dependent variable. Each category of spending has its own dynamic to a certain extent, as does each type of dependent variable. For example, higher education seems very responsive to federal grants, whereas K-12 education seems less so. Overall, education spending programs appear very responsive to competing demands for dollars in the form of more AFDC/TANF recipients, but this seems to have no effect on highway expenditures except when conceived of in terms relative to other forms of spending (first model in table 1). The influence of demands for competing spending varies by program, but the findings for education fit our view of competition for scarce resources at the state level, with demands for consumption spending pitted against demands for investment spending, confirming the research of Nicholson-Crotty, Theobald, and Dan Wood (2006) and fitting in to the larger discussion of budgetary trade-offs (Berry and Lowery 1990; Hendrick and Garand 1991).

The influence of all these independent variables is also dependent on the way in which spending is measured, and our different measures of state spending are designed to assess different things. For example, the federal grant variable is positive in all models save one but is only significant across all the models for higher education spending. This indicates that K-12 and highways grants do not lead to an overall expansion of spending to facilitate increases for these programs; instead, these federal grants influence states to reallocate money across different programs in the state budget. For higher education, it does appear that the states will actually increase per capita expenditures as well as their share of per capita income, evidence of the oft-noted flypaper effect.

The measure of personal income was significant in both models that included it for K-12 education but only in the budget share models for higher education and highways. For 
K-12 spending, higher amounts of per capita personal income growth lead to greater per capita expenditures. For the other two types of spending, personal income growth leads to more allocations to these programs as a proportion of the budget, but not more expenditures. It is possible that demand for other types of spending is lessened during periods of economic expansion, and this is reflected in a greater relative allocation to higher education and highways.

The convergence variable was significant in all the models providing further evidence that neighboring states share similar spending patterns over time. This is an important observation, though, in the future, scholars should more carefully consider the mechanism by which states respond to one another's spending patterns. There does not seem to be any consistent evidence of a race to the top or bottom in developmental spending, however.

Notable across all models is the general lack of significance for the coefficients of the partisanship variables. As noted at the outset of the article, these types of spending are generally viewed as less political than redistributive spending, and perhaps, it is therefore not very surprising that partisanship does not influence developmental spending. However, our analysis indicates that politics is an important determinant of state developmental spending. Ideology had a strong and consistent influence on spending on highways and K-12 education, though it had no effect on higher education spending. This indicates that liberal states spend less on highways but more on K-12 education, regardless of how spending is measured.

\section{Conclusion}

These models demonstrate the factors that on average determine state allocations to developmental programs. But our analysis of state spending patterns allows for some commentary regarding why relative state allocations to developmental programs have been reduced in recent years. For example, personal income growth is an important determinant of spending; however, it has generally slowed in recent decades. In the boom of the latter half of the 1990s, personal income grew in real terms approximately $2 \%$ per year, compared to approximately $4 \%$ per year in the boom years of the late 1960s. Of course spending on investment programs will be greater when fewer people need the services of even the limited welfare state that exists in the United States because they are making a better living. It is also possible that during periods of rapid economic growth, people have more confidence in and are therefore more willing to invest in the future. This appears to be the most important for K-12 spending.

Like economic growth rates, the emphasis on developmental or investment programs in federal grants to the states has decreased over the last few decades. In the latter half of the 1960 s, approximately $59 \%$ of money that the federal government sent to the states was devoted to education or highway spending. In contrast, by 2004 , only $27 \%$ of federal grants to the typical state were intended for use in these developmental programs. The reasons for this shift are well known. The federal and state governments have increased eligibility for various health and welfare programs, the costs of which have expanded rapidly. In Alabama, for example, the limit for Medicaid eligibility is only 
about $26 \%$ of the poverty line. Further, in many instances, programs like Medicaid require state matching funds. With health care costs increasing well above the rate of inflation, we can expect that additional pressures will be applied to states to increase spending on health care programs. Since states are generally limited in terms of the debt they can accumulate, this will often lead to downward pressure on state developmental and investment spending. The states may also face added pressures to show that current allocations are used effectively. In our analyses, grants were consistently influential for higher education, and federal and state policymakers may want to ensure that the money is spent wisely.

As the resource requirements of other programs expand in the coming years with greater health care costs projected well into the future, states will continue to grapple with these difficult issues. Recognizing their precarious fiscal position, many public universities are now essentially public in name only, with tuition rates little different from private universities and many troubling implications for quality and access (Ehrenberg 2006). Similarly, privatizing state highways by providing long-term leases to private companies that are responsible for maintenance has become a serious option for many states (Kim 2006). Unfortunately, given the generally lower rates of economic growth and the lack of emphasis on developmental programs in federal aid to the states, it does not appear that this situation will ease any time soon.

We believe we have a decent understand of why states have made certain budgetary decisions in recent years regarding investment spending. Given the states' funding decision regarding highways and higher education, it seems safe to assume that state budgeters do not feel as if they have the necessary resources to adequately fund these programs. This is clear given budgetary inadequacies in higher education in many states and recent discussions of severe underfunding of highway and bridge maintenance. Yet, critics of government spending are correct in pointing out that in virtually all government programs, states spend much more in inflation adjusted dollars than they did many years ago. This is even true of developmental programs, though as we noted at the outset, spending on these programs has increased much less rapidly than other types of programs. Identifying the "correct" level of government expenditure on a given program is a perennially vexing subject for policy makers, but it seems that many people in the United States believe that we should certainly be doing more of something to develop our human and physical capital, whether or not this necessarily requires additional expenditures. 


\section{REFERENCES}

Alt, James E., and Robert C. Lowery. 2000. A dynamic model of state budget outcomes under divided partisan government. Journal of Politics 62:1035-69.

Bailey, Michael A., and Mark Carl Rom. 2004. A wider race: Interstate competition across health and welfare programs. Journal of Politics 66:326.

Bailey, Michael A., Mark Carl Rom, and Matthew T. Taylor. 2004. State competition in higher education: A race to the top or a race to the bottom? Economics of Governance 5:5375.

Basken, Paul. 2006. "Asia gains on U.S., Europe in education, OECD finds," Bloomberg News, September 12, http://www.Bloomberg.com (accessed July 17, 2008).

Beck, Nathaniel. 2001. Time-series cross-section data: What have we learned in the past few years. Annual Review of Political Science 4:271-93.

Beck, Nathaniel, and Jonathan N. Katz. 1995. What to do (and not to do) with time-series cross-section data. The American Political Science Review 89:634-47.

Berry, William D., and David Lowery. 1990. An alternative approach to understanding budgetary tradeoffs. American Journal of Political Science 34:671-705.

Berry, William D., Evan J. Ringquist, Richard C. Fording, and Russel L. Hanson. 1998. Measuring citizen and government ideology in the American states, 1960-93. American Journal of Political Science 42:327-48.

Brace, Paul. 1993. State government and economic performance. Baltimore, MD: Johns Hopkins Univ. Press.

Carey, Kevin. 2002. Overview of K-12 education finance. Washington, DC: Center on Budget and Policy Priorities.

Chubb, John E. 1985. The political economy of federalism. The American Political Science Review 79:994-1015.

Council of State Governments. 1964-2004. The Book of the States, vols. 15-36. Lexington, KY: Council of State Governments.

Dye, Thomas R. 1966. Politics, economics and the public: Political outcomes in the American states. Chicago, IL: Rand McNally.

.1979. Politics vs economics: The development of literature on policy determinism. Policy Studies Journal 7:652-62. 
- 1988. Explaining government contraction: A demand-side model for education in the States. The Western Political Quarterly 41:779-90.

Ehrenberg, Ronald G. 2006. What's happening to public higher education? New York, NY: Praeger.

Ferriss, Susan. 2007. College-grad shortage seen. The Sacramento Bee, May 24.

Garand, James C. 1985. Partisan change and shifting spending priorities in the American States, 1945-1978. American Politics Quarterly 13:355-91.

Garand, James C., and Rebecca M. Hendrick. 1991. Expenditure tradeoffs in the American states: A longitudinal test, 1948-1984. The Western Political Quarterly 44:915-40.

Gray, Virginia. 1974. Expenditure and innovation as dimensions of "Progressivism": A note on the American states. American Journal of Political Science 18:693-99.

Hendrick, Rebecca M., and James C. Garand. 1991. A pooled analysis. Journal of Public Administration Research and Theory 1:295-318.

Hines, James R., Jr., and Richard H. Thaler. 1995. Anomalies: The flypaper effect. The Journal of Economic Perspectives 9:217-26.

Hwang, Sung-Don, and Virginia Gray. 1991. External limits and internal determinants of public policy. Western Political Quarterly 44:277-98.

Jacoby, William G., and Saundra K. Schneider. 2001. Variability in state policy priorities: An empirical analysis. Journal of Politics 63 (2): 544-68.

Jones, Bryan D. 1990. Public policies and economic growth in the American states. Journal of Politics 52:219-33.

Kane, Thomas J., Peter Orszag, and David L. Gunter. 2002. State support for higher education, Medicaid and the business cycle. Washington, DC: Brookings Institution.

Katz, Jonathan N., and Gary King. 1999. A statistical model for multiparty electoral data. The American Political Science Review 93:15-32.

Keen, Michael, and Maurice Marchand. 1997. Fiscal competition and the pattern of public spending. Journal of Public Economics 66:33-53.

Kim, Theodore. 2006. States considering privatizing highways can study Indiana toll road experience. USA Today October 16, Online Edition. 
Knight, Brian. 2002. Endogenous federal grants and crowd-out of state government spending: Theory and evidence from the federal highway aid program. The American Economic Review 92:71-92.

Lindblom, Charles. 1977. Politics and markets. New York, NY: Basic Books.

Lurie, Irene. 1998. Watching the race: Where you sit affects what you see. Publius 28:89-94.

Nice, David C. 1987. Federalism: The politics of intergovernmental relations. New York: St. Martin's.

Nicholson-Crotty, Sean, Nick A. Theobald, and B. Dan Wood. 2006. Fiscal federalism and budgetary trade-offs in the American states. Political Research Quarterly 59:313-21.

Peterson, Paul E. 1981. City limits. Chicago, IL: Univ. of Chicago Press.

—. 1995. The price of federalism. Washington, DC: Brookings.

Phillips, Justin H. 2004. Does market competition or electoral competition drive state tax policy. Paper presented at the Annual Meeting of the American Political Science Association, Chicago, IL, September 2-5, 2004.

Saiz, Martin. 2001. Politics and economic development: Why governments adopt different strategies to induce economic growth. Policy Studies Journal 29:203-14.

Saulny, Susan, and Jennifer Steinhauer. 2007. Bridge collapse revives issue of road spending. The New York Times August 7, Online Edition.

Schram, Sanford F. 1998. Introduction welfare reform: A race to the bottom? Publius 28:1-8.

Smith, Kevin B., and J. Scott Rademacker. 1999. Expensive lessons: Education and the political economy of the American state. Political Research Quarterly 52:709-27.

Sterngold, James. 2007. Prisons' budget to trump colleges. San Francisco Chronicle May 21, A1.

Wildavsky, Aaron. 1964. The politics of the budgetary process. Boston, MA: Little Brown. 